Удк 340.15

Пальченкова В. М.,

доктор юридичних наук, професор, професор кафедри конституційного, адміністративного та трудового права Запорізького національного технічного університету

\title{
ОЛЕКСАНДРІВСЬКИЙ ТЮРЕМНИЙ ЗАМОК: ДАТА ЗАСНУВАННЯ
}

У статті на основі сучасної та дореволюційної літератури, архівних джерел реконструюється історія будівництва Олександрівського тюремного замку, який знаходився на території повітового міста Олександрівськ Катеринославської губернії, нині місто Запоріжжя.

Ключові слова: колодники; місто Олександрівськ; Російська імперія; острог; тюремний замок.

В статье на основе современной и дореволюционной литературы, архивных источников реконструируется история строительства Александровского тюремного замка, который находился на территории города Александровска Екатеринославской губернии, в настоящее время город Запорожье.

Ключевые слова: колодники; город Александровск; Российская империя; острог; тюремный замок.

Постановка проблеми. Система місць ув'язнення будь-якої держави нерозривно пов'язана $з$ особливостями її політичного й соціально-економічного розвитку в конкретний історичний період. Вона являє собою складне явище, оскільки є частиною каральних органів та відіграє значну роль не лише у здійснені репресивної державної політики, а й певним чином впливає на всі сфери суспільного життя. Можна вказати, що відповідний вплив пенітенціарна політика Російської імперії мала на Південний регіон сучасної України, що вимагає необхідності продовження вивчення функціонування місць позбавлення волі в історичній ретро- спективі, у тому числі на рівні досліджень в окремих регіонах держави, наприклад у Запорізькій області.

Аналіз останніх досліджень i публікацій. Історико-правові питання становлення та розвитку кримінально-виконавчої системи України вже не $\epsilon$ абсолютно «білою плямою» в історіографії, як це було, коли працював над монографією «Каральний апарат самодержавства в Україні у кінці XIX - на початку XX ст.» О.Н.Ярмиш. Саме ця робота дала поштовх для подальших досліджень різних історико-правових аспектів функціонування пенітенціарної системи України. На монографічному рівні продовжили вивчення історії 
в'язничної системи О. М. Григор'єв, I. В. Іваньков, О. П. Неалов, В. В. Россіхін, О. В. Сокальська, М. М. Яцишин. Останнім часом почалося розроблення питань, присвячених регіональним особливостям виникнення та розвитку окремих тюремних установ, дисертаційне дослідження I. 0. Левчука присвячене місцям позбавлення волі Волинської губернії. Дослідженням регіональної історії пенітенціарних установ займаються й фахові історики, зокрема історію в'язниць у Запорізькому краї вивчають П. П. Кравчук, С. Д. Рев'якін та ін.

Виклад основного матеріалу. 10 травня 1770 р. військовою колегією Російської імперії були затверджені пункти під назвою «Про улаштування лінії по ріках Берді та Московці», а 2 вересня 1770 р. Катерина II підписала Указ про будівництво Дніпровської оборонної лінії. Відповідно до Указу за п’ять років була побудована укріплена фортифікаційна лінія, що розтягнулася на 196 верст і мала у своєму складі сім фортець - Олександрівську, Микитинську, Кирилівську, Григорівську, Олексіївську, Захарівську та Петрівську. За однією з версій усі вони названі на честь воєначальників російської армії, зокрема Олександрівська - на честь генерал-фельдмаршала Олександра Голіцина. Саме 3 будівництвом Дніпровської оборонної лінії пов'язано становлення та розбудову в'язничної системи на Запоріжжі.

У 1774 р. головний командир Нової Дніпровської лінії В. О. Чертков написав рапорт Г. О. Потьомкіну 3 проханням вирішити питання із Ceнатом та імператрицею стосовно відсилки всіх засуджених у південному краї до каторги на роботи 3 будівництва Дніпровської лінії, зок- рема, Олександрівської фортеці. До кінця XVIII ст. Олександрівська фортеця почала служити місцем заслання «колодників» (арештант, в'язень у колодках або інших кайданах) на строкові каторжні роботи і на постійне їх поселення.

У фундаментальній праці, присвяченій історії виникнення міста Олександрівська, Я. П. Новицький висловлює думку про те, що поява перших партій колодників припадає на 1775 р., рік ліквідації Запорізької Січі. У 1776 р. прийнято рішення про відсилку на каторжні роботи до Олександрівської фортеці всіх засуджених до каторги в центральних губерніях Російської імперії. Заслані прибували в цей регіон до початку російсько-турецької війни у 1787 р. [1, c. 299, 442]. Історик Р. Л. Молдавський, досліджуючи зміни, що відбулися в етнічному складі Запорозьких Вольностей під час будівництва Дніпровської лінії, наводить дані про постійне збільшення контингенту зсильнокаторжних в Олександрівській фортеці, 1774 р. - 130, 1779 - 167, 1782 - 262 [2, с. 126]. 3 іншого боку , після остаточного знищення царатом Запорозької Січі етапом були відправлені до Сибіру тисячі українців лише за те, що вони були «малоросами» й не схилялися перед російськими загарбниками. А на вивільнені багатющі українські землі масово відправляли 3 російських губерній здебільшого порочний, розбещений люд. Я. П. Новицький констатує запустіння і знелюднення раніше квітучого краю уздовж Дніпровської лінї та катастрофічне зменшення «сімейного люду» та народжуваності. У зв'язку із цим зсильнокаторжні, як чоловіки, так і жінки, офіційно отримали дозвіл на одруження. Цікавою $є$ 
статистика, подана Я. П. Новицьким, за 1775 р. В Олександрівській фортеці народилися від військових - 7 осіб, малоросіян та «поселенців» - 4 особи, а в родинах зсильнокаторжних 2 особи [1, с. 213-214]. Отже, українці серед народжених в Олександрівську складали щонайбільше 30 \%, а зсильнокаторжні - 15 \%. Як правильно зауважує П. П. Кравчук, «колодники без перебільшення ставали піонерами багатоликої державної колонізації, що інтенсивно проводилася у Південній Україні в останній чверті XVIII ст.» $[3$, с. 7].

Отже, цілком зрозуміло: коли $\epsilon$ в'язні, то для їх охорони та утримання повинні бути наглядачі й місця утримання. Очевидно, що одним із нагальних завдань першого коменданта Олександрівської фортеці полковника В. Ф. Фредездорфа стало розміщення колодників. Можемо припустити, що спочатку для їх утримання споруджувалися спеціальні землянки, де арештантів охороняли та виводили на роботу солдати.

У 1783 р. у фортеці відзначається значне збільшення чисельності контингенту зсильнокаторжних. Проте, як свідчать документи Олександрівської Ратуші за 1787-1806 рр., до 1803 р. в Олександрівському посаді поліції та, очевидно, і в'язниці як окремої споруди не існувало взагалі. Можемо припустити, що охорону в'язнів та й інші поліцейські функції здійснювали солдати інвалідної роти, що була створена в Олександрівську в 1800 р. Лише у 1803 р. з'являється поліція, і засуджені до позбавлення волі до 1806 р. утримуються в «сінях поліції» [1, с. 254-255, 300]. Треба сказати, що такий стан речей був характерним для того часу майже в усіх повітових містах Росій- ської імперії - місця ув'язнення облаштовувалися при різноманітних «присутственних» місцях (урядових установах) і конкретно при поліцейських відділках [4, с. 299].

5 червня 1806 р. Олександрівський посад (у Російській імперії - передмістя або селище, де жили ремісники, торговці та міська біднота) був перейменований у повітове місто, тоді ж міська Ратуша, за відомостями Я. П. Новицького, найняла темний, сирий кам'яний погріб (яму), до якого й були переведені арештанти. Але такий погріб, звісно, не міг забезпечити всіх новоприбулих засуджених. 3 цього приводу виникла суперечка між Катеринославським губернатором i городничим, з одного боку, та Ратушею, з іншого, хто та на які кошти буде споруджувати тюрму $[1$, с. $254-$ 255]. Очевидно дискусія, що розгорнулася між повноважними посадовцями, була плідною і дала певні результати, оскільки в плані міста Олександрівська за 1806 р., який подано Я. П. Новицьким під номером 22, міститься острог, тобто тюрма, обнесена дерев'яним частоколом.

На жаль, опис Олександрівського острога не зберігся. Але завдяки тюремному інспектору Чернігівської губернії В. Д. Краінському, а пізніше М. М. Гернету, до нашого часу дійшли досить детальні описи острогів у повітових містах Чернігівської та Полтавської губерній (на той час Малоросійська губернія), що існували та функціонували наприкінці XVIII ст. [5, c. 11-38; 4, с. 296-314]. Згідно із цими описами, ділянка острогу мала форму прямокутника чи квадрата, який був огороджений з усіх боків парканом. Паркан складався з колод, здебільшого дубових, загострених доверху. Колоди повинні були бути товщиною 6 
вершків (міра довжини, що дорівнює 4,4 cм), закопані на три аршини (давня східнослов'янська міра довжини, що дорівнює 0, 711 м) у землю. Над поверхнею землі ці загострені колоди (частоколи) піднімалися щонайменше на три сажені (давня східнослов'янська лінійна міра, яка дорівнює 2,134 м). У деяких повітових містах частоколи ставилися з усіх чотирьох сторін у два ряди, і тоді колоди зовнішнього ряду вкопувалися глибше колод внутрішнього ряду. Така огорожа була дуже надійною. Арештанти острога здебільшого заковувалися в кайдани та різні ланцюги.

За свідченнями Д. В. Країнського, більшість таких острогів наприкінці XVIII ст. перебувала у вкрай занедбаному, майже зруйнованому стані й не витримувала дедалі більшого навантаження з боку засуджених до позбавлення волі. 20 квітня 1800 р. Сенат Російської імперії виділяє значні кошти на ремонт та будівництво 12 нових острогів у Малоросійській губернії. За розпорядженням губернської адміністрації було розроблено два розряди острогів - один для більших міст, інший - для менших. Згідно $з$ кошторисом, на острог у великих міста виділялася сума в розмірі 4977 крб 20 коп., для менших 4313 крб 10 коп. Будівництво нових острогів передбачалося за старою схемою, єдине, що відрізняло «новий» острог від «старого»- це проектування кам'яного фундаменту для корпусів. Проте, як, до речі, завжди, кошти на таке масштабне будівництво в державі були відсутні. Завдяки ініціативам Малоросійського губернатора князя О. Б. Куракіна Олександром I 25 квітня 1803 р. видано іменний указ, згідно з яким будівництво острогів санкціонувалося за рахунок як державних, так і місцевих коштів. Передбачалося споруджувати в Малоросії остроги з розподілом арештантів на три групи: перша - смертовбивці, святотатці, зрадники, розбійники, фальшивомонетники; друга злодії, шахраї, статеві злочинці; третя - затримані за борги та інші. Режим утримання кожної групи засуджених повинен був відрізнятися один від одного. Так, засуджені першої групи, які вважалися найнебезпечнішими, утримувалися у кайданах (залізні або сталеві браслети, з'єднані ланцюгом, що надягають на руки або ноги ув'язнених для обмеження рухів) зі стільцем, вікна в їх камерах повинні бути загратовані. Злочинці другої групи мали утримуватися в камерах без грат на вікнах, а замість кайданів мати на собі колодки (дерев'яна конструкція, з прорізами для голови й рук, однієї або двох ніг людини). А для третьої групи засуджених повинні бути відведені приміщення при городничому [6].

Одним з перших такий «новийстарий» острог було побудовано в місті Чернігові. Він хоча дещо й змінив свій вигляд порівняно з попереднім місцем утримання в'язнів, але не відповідав вимогам часу, тому майже одразу було поставлено питання про його реконструкцію. За проектом князя О. Б. Куракіна відбувається грандіозна перебудова Чернігівського острогу. У 1803 р. він був обнесений цегляним тюремним парканом з чотирикутними вежами. На будівництво цієї споруди витратили 980 тис. цегли і значну для того часу суму - 16574 крб 10 коп. Острог після цього став нагадувати справжній середньовічний замок, саме так згодом стали називати місця ув'язнення - тюремний замок. 
Можемо припусти, що саме за такою схемою розвивалися події тюремного будівництва й у невеликому повітовому місті Олександрівську. Спочатку, у 1806 р., побудовано острог за старим планом, але дуже швидко він морально й технічно застарів, тому наступним кроком стало будівництво тюремного замку. Такий розвиток подій підтверджується нормативними актами, уміщеними в Повному зібранні законів Російської імперії. Так, 14 квітня 1808 р. Олександром I було затверджено доповідь міністра внутрішніх справ (на той час ним став колишній Малоросійський генерал-губернатор князь О. Б. Куракін) про будівництво тюремних замків у всіх губерніях за планом Малоросійських губерній [7], 11 грудня 1811 р. вийшов циркуляр, у якому містилися правила складання планів та кошторису будівництва тюремних замків. 24 квітня 1821 р. вже новий міністр внутрішніх справ В. П. Кочубей, продовживши справу свого попередника, звернувся до імператора із запискою про плани повітових тюремних будівель, на якій імператор наклав резолюцію подати йому особисто розроблені схеми тюремних будівель [8]. I нарешті 28 лютого 1823 р. міністр внутрішніх справ доповідав імператору про будівництво в повітових містах тюремних замків згідно 3 наданими планами будівель [9].

Одним із невирішених питань, що викликає дискусію в сучасних дослідників історії тюремних установ Олександрівська, є дата побудови тюремного замку. Існує дві основні версії, кожна з яких певною мірою має право на існування.

За першою тюремний замок побудовано в 1839 р. [3, с. 7]. Прибічники цієї версії - відомий запорізь- кий краєзнавець Л. Адельберг та історик П. П. Кравчук. Основними джерелами доказів стали фото, що зберігається у фондах Державного архіву Запорізької області, під яким $\epsilon$ напис «Головний фасад виправної установи міста Олександрівська. Побудови 1839 р.», а також відсутність в описі міста Олександрівська 1837 р. [10] (зроблений Я. Новицьким) будь-яких згадок про тюремний замок.

Іншої версії дотримується С. Рев'якін [11, с. 37-38]. Він вважає, що більш достовірною $є$ інформація, яка міститься в матеріалах Олександрівської міської управи, датованих 28 травня 1904 р. У них повідомляється, що на запит Катеринославського тюремного інспектора про дату заснування тюремного замку чиновник управи відповів: «Ваше Високоблагородіє, тюремний замок існує в Олександрівську з 1825 р. Що стосується місця розташування призамкових інших споруд, таких як-то: тюремної лікарні, кам'яної комори та інше, то такі побудовані Тюремним відділенням у 1883 р. під час перебування предводителя дворянства нині покійного Є. І. Шабельського».

На нашу думку, саме в цьому документі дано чітку відповідь на запитання про час початку роботи Олександрівського тюремного замку - 1825 р. А в наступні роки аж до 1883 р.,продовжували добудовувати на території тюрми всілякі господарські об'єкти, у тому числі лікарню. Непрямим свідченням підтвердження достовірності цієї дати $є$ той факт, що в період підготовки відповіді Олександрівської міської управи Катеринославському тюремному інспектору в цій установі працював безсумнівний авторитет історії міста Олександрівська - Я. П. Новицький. Найбільш імо- 
вірно, що, готуючи відповідь на запит, чиновники управи радилися $з$ дослідником, і саме він підказав дату побудови місцевого тюремного замку. Крім того, вивчаючи текст складеного Я.П.Новицьким статистичноекономічного стану міста Олександрівська за архівними даними 1829 р. (більш ранній період), ми знаходимо відомості про функціонування тюремної установи. Указується, що протягом 10 років, з 1819 по 1829 р., у міській тюрмі утримувався 4641 арештант. За цей час покарано 293 особи. У міській тюрмі утримується 26 осіб [12, с. 306]. I нарешті, С. Рев'якіним було детально вивчено фото, що зберігається у фондах Запорізького архіву. Дослідник звертає увагу на те, що у даті «1839 рік» цифра 9 дописана іншим шрифтом. Хто їі дописав і за яких обставин - установити сьогодні важко. Можливо, головний фасад тюремного замку справді побудовано в 1839 р., але це ніяк не $є$ підтвердженням того, що сам тюремний замок споруджено в цей рік. Навпаки, спочатку треба «запустити в роботу» корпуси для утримання арештантів, по-суті дати можливість функціонувати самій тюремній установі, а вже потім, коли держава виділить кошти, цю жахливу цитадель закрити від людського ока пишним головним фасадом, щоб весь люд милувався. Саме так і сталося. Надзвичайно привабливим побачив Олександрівський тюремний замок український письменник, етнограф та мандрівник О. С. Афанасьєв-Чужбинський у 1858 р. під час відвідування міста. Свої враження від Олександрівська він описав, так: «Знаходячись над Дніпром, він ніяк не міг зробитися краще порядного села, й перебиваючись абияк своєю копійчаною торгів- лею..., не представляє нічого втішного навіть для голодного подорожнього... В місті, зазвичай, мертва тиша, i майже ніякої промисловості... Краща будівля в Олександрівську - острог, який як кажуть наповнюється значною кількістю колодників, тому що це великий повіт» [13, с. 138-141]. Далі на фото зазначається: «Зразковий фасад для будівництва виправних установ по Катеринославській губернії. Січень 1829 року. Реконструкція». Виявляється, що Головний фасад Олександрівського тюремного замку зовсім не єдиний, а лише зразковий для повітових тюремних установ Катеринославської губернії, та й розроблений він на 10 років раніше.

Проіснував Олександрівський тюремний замок до 1919 р. Спочатку в березні 1918 р. під час пожежі були пограбовані тюремна церква та сама тюрма. А в жовтні 1919 р. тюремна будівля була підірвана та остаточно знищена загоном анархістів під керівництвом Н. I. Махна.

Висновки. 3 будівництвом Дніпровської фортифікаційної лінії тісно пов'язано становлення тюремних установ у місті Запоріжжі (Олександрівську). Цей процес тривав у період з 1775 р. по 1825 р., до початку введення в дію Олександрівського тюремного замку. Становлення в'язниці відбувалося в кілька етапів: перший - 3 початку 70-х рр. XVIII ст. до 1803 р. характеризувався активним використанням зсильнокаторжних із центральних регіонів Російської імперії на будівництві Олександрівської фортеці та відсутність будівлі в'язниці як такої; другий - 18031806 рр. - облаштуванням спеціального приміщення для утримання арештантів у «сінях поліції»; третій 1806-1825 рр. - збільшення кількос- 
ті арештантів, утримання їх у дерев'яному острозі до початку роботи тюремного замку. Необхідно підкреслити, що пенітенціарна політика суттєво вплинула на подальший соціально-економічний розвиток Південної України, вона стала частиною великої експансії Російської імперії земель запорозького козацтва.

Сьогоднішня система виконання покарань знаходиться у вкрай незадовільному стані через її хронічне недофінансування, відсутність постійної допомоги з боку суспільства та мінімізованої допомоги з боку держави. Необхідно зазначити, що на території сучасної України значна частина приміщень, у яких розташовані установи виконання покарань, збудовані навіть не за радянських часів, а у XVI-XVIII ст. Це, зокрема, Львівський слідчий ізолятор, розта- шований на вул. Городоцькій, який $\epsilon$ одним з найстаріших в Україні (йому понад 400 років), Лук'янівський слідчий ізолятор - будівля, за визначенням архітекторів, істориків, політиків, $\epsilon$ важливою в історичному сенci, збудована у 1863 р., Чернігівській слідчий ізолятор та інші.

Історичні споруди, що залишили свій кривавий слід в історії України, в'язниці окупаційних режимів, де крім осіб, що скоїли загальнокримінальні злочини, гинули сотні і відбували покарання тисячі українських патріотів, не може бути просто знищено. Ці споруди повинні бути під наглядом та охороною держави як нагадування про геноцид, тортури тоталітарного режиму і з метою недопущення подібного в майбутньому України.

\section{Список використаних джерел}

1. Новицький Я. П. История г. Александровска в связи с историей возникновения крепостей Днепровской линии (1770-1806 гг). Новиџький Я. Твори у 5ти томах. Т. 1. Запоріжжя. ПП «АА Тандем». 2007. С. 184-303.

2. Молдавський В.Л. Зміни в етнічному складі населення Запорозьких Вольностей за часів будівництва Нової Дніпровської лінії укріплень. Державна етнонаціональна політика: правовий та культурологічний аспекти в умовах Південної України. Зб. наук. праць. Запоріжжя : ЗНТУ, 2005. С. 125-127.

3. Карпенко В.А., Кравчук П.П. 3 історії місць ув'язнення Запорізького регіону. Запоріжжя : $38 \mathrm{c}$.

4. Гернет М. Н. История царской тюрьмы. Т. 1 (1762-1825). 3-е изд. Москва : Гос. изд-во юрид. лит-ры, 1960. 386 с.

5. Краинский Д. В. Материалы к исследованию истории русских тюрем в связи с историей учреждения общества попечительного о тюрьмах. Чернигов: Типография губернского земства, 1912.133 с.

6. Именной, данный Малороссийскому генерал-губернатору князю Куракину «0 устроении острогов по Малороссийским губерниям; о разделении колодников на три разряда и о назначении особого режима содержания». ПСЗ-1. T. XXVII (18021803). № 20728.

7. О строении тюремных замков во всех губерниях по планам высочайше утвержденным для Малороссийской губерний. ПСЗ-1. Т. XXX (1808-1809). № 22963.

8. О планах уездных тюремных замков. ПСЗ-1. T. XXXVII (1820-1821). № 28617 . 
9. О постройке в уездных городах тюремных помещений, сообразно с приложенным планом. ПСЗ-1. Т. XXXVIII (1822-1823). № 29342.

10. Новицький Я.П. Город Александровск в 1837 году. Статистическое описание по архивным данным. Новицький Я. Твори у 5-ти томах. Т. 1. Запоріжжя. ПП «АА Тандем». 2007. С. 312-323.

11. Рев'яквін С.Д. Історія запорізьких в'язниць 1806-2016 рр. Запоріжжя : Дніпровський металург, 2017. 818 с.

12. Новицький Я.П. Статистико-экономическое состояние гор. Александровска и уезда по архивным данным 1829 года. Новицький Я. Твори у 5-ти томах. Т. 1. Запоріжжя. ПП «АА Тандем». 2007. С. 304-311.

13. Афанасьев-Чужбинский А.С. Поездка в Южную Россию. Часть первая. Очерки Днепра. СПб : Типография Морского министерства, 1861. 465 с.

\section{Palchenkova,}

Doctor Of Law, Professor,

Professor of the department of constitutional, administrative and labor law Zaporizhzhya

National Technical University

\section{ALEXANDER'S PRISON CASTLE: FOUNDATION DATE}

In the article on the basis of modern and pre-revolutionary literature, archival sources, the history of the construction of Alexander's prison castle is reconstructed (was on the territory of the county city of Alexandrovsk of the Katerinoslav province, now the city of Zaporozhzhya).

It was find out the construction of the Dnipro defense line is connected with the establishment and development of a prison system in Zaporozhzhya. This process lasted from 1775 to 1825, before the Alexander's prison castle put in operation.

At the end of the eighteenth century Alexander's fortress began to serve as a place of exile of "convict in the stocks" (a prisoner, a prisoner in the shackles or other shackles) for urgent hard labor and their permanent settlement. The formation of the prison took place in several stages: the first - since the early 70's XVIII century until 1803 was characterized by the active use of exiles from the central regions of the Russian Empire at the construction of the Alexander's fortress and the lack of a prison building as such; the second one: 1803-1806 years - the arrangement of a special room to keep the prisoners in the «police halls»; the third 1806-1825 years - increase of all the prisoners, keeping them in a wooden prison before the entry into action of the prison castle.

It is emphasized that the penitentiary policy significantly influenced the further socio-economic development of the Southern Ukraine; it became a part of the great expansion of the Russian Empire of the Zaporozhian Cossacks.

Ключові слова: convict in the stocks; Alexandrovsk city; the Russian Empire; prison; prison castle.

Надійшла до редакції 02.12.2018 